\title{
Physico-Chemical Analysis, Cooking Quality and Acceptability of Minor Tubers
}

\author{
Divya Parmeshwar Mesta ${ }^{1^{*}}$, Pushpa Bharati ${ }^{1}$ and Sunanda K. Itagi ${ }^{2}$ \\ ${ }^{1}$ Department of Food Science and Nutrition, College of Rural Home Science, University of \\ Agricultural Sciences, Dharwad, Karnataka, India \\ ${ }^{2}$ Department of Human Development and Family Studies, College of Rural Home Science, \\ University of Agricultural Sciences, Dharwad, Karnataka, India \\ *Corresponding author
}

\begin{tabular}{|c|c|}
\hline & A B S T R A C T \\
\hline & \multirow{5}{*}{$\begin{array}{l}\text { Tuber crops find an important place in the dietary habits of the farmers; especially in } \\
\text { attaining food security of the tribal population. A number of tubers are gathered by tribal } \\
\text { population and consumed as a substitute to cereals or along with cereals. Significant } \\
\text { difference was observed among fourteen different minor tubers for physical and physico } \\
\text { chemical characteristics. The mean values for length }(18.02 \mathrm{~cm}) \text {, width }(7.75 \mathrm{~cm}) \text {, } \\
\text { circumference }(20.70 \mathrm{~cm}) \text {, weight }(573.75 \mathrm{~g}) \text {, volume }(542.12 \mathrm{ml}) \text {, and bulk density } \\
(1.03 \mathrm{~g} / \mathrm{ml}) \text { was noted. Dry matter }(13.34-37.90 \%) \text {, TSS }\left(5.27-12.477^{\circ} \mathrm{B}\right) \text {, pH }(6.20 \text { to } 7.30) \text {, } \\
\text { and titratable acidity }(0.04-0.08 \%) \text { of the selected minor tubers varied. Cooking time } \\
\text { ranged from } 11 \text { min for alocasia, arial yam, Chinese potato and wild yam to } 20 \text { min for } \\
\text { elephant foot yam. Weight gain ranged from } 5.17 \text { per cent for greater yam (Neelam) to } \\
43.97 \text { per cent for Tannia. Lesser yam, greater yam (lion foot type), greater yam (wild } \\
\text { edible type) and Taro were highly acceptable with acceptability index of } 93.21-81.97 \text {. }\end{array}$} \\
\hline & \\
\hline $\begin{array}{l}\text { Minor tubers, Yams, } \\
\text { Taro, Cassava, } \\
\text { Arrowroot. }\end{array}$ & \\
\hline Article Info & \\
\hline $\begin{array}{l}\text { Accepted: } \\
\text { 24 September } 2017 \\
\text { Available Online: } \\
10 \text { November } 2017\end{array}$ & \\
\hline
\end{tabular}

\section{Introduction}

Minor tuber crops are the underutilized crops and are the third important food crops after cereals and legumes and are either a staple or subsidiary food for about one-fifth of the world population.

They contribute about six per cent of the world's dietary calories, play an important role as a source of animal feed besides being significant raw material for industrial products. In terms of annual volume of production, cassava, potato, and sweet potato rank among the top 10 food crops produced in developing countries. The tuber crops are consumed as a part of religious rituals like Thiruvathira and Karthika. Tribals eat yams for maintaining their physical health and also for medicinal benefits (Viswanathan, 2004).

Tuber and root crops are carbohydrate-rich foods (Hoover, 2001). In addition to the high starch content, these vegetables further contain other carbohydrates such as MALTOS, FOS and inulin (Judprasong et al., 2011; Moongngarm et al., 2011). Though few studies indicate the presence of oligosaccharides in raw tubers/roots but it is worth noticing that humans consume cooked 
forms of these foods. It is important to stress that thermal treatment could lead to substantial changes in the compounds present in foods quantitatively and qualitatively (Lai et al., 2013). In addition, the preprocessing operations prior to cooking can influence many changes.

Most of the root and tuber crops are rich in energy, minerals, vitamins, antioxidants and dietary fibre. They may play an important role in mitigating hidden hunger through diet diversification and have proved to be life sustaining crops in times of natural calamities and famine, when all other crops fail; tubers sustain (Anon, 2013). There are numbers of under exploited minor tubers that play an important role in the dietary habits of the farmers and for medicinal uses. They are also called as future crops of mankind. Information on cooking quality and acceptability of these tubers is scanty. Hence the present study has been undertaken with the objective to evaluate the physico chemical properties, cooking quality and acceptability of minor tubers.

\section{Materials and Methods}

\section{Collection of materials}

Fourteen different types of minor tubers grown in red laterite soil, planted in the month of March-April and harvested in the month of September-October 2016 were collected from the farmers of Joida, Uttara Kannada District. The collected tubers were brought to the laboratory immediately and processed. The tubers were washed in running water to remove the adhered soil and other dirt particles and used for further study.

\section{Physico-chemical analysis}

The physico chemical characteristics viz., skin colour, flesh colour (visual observation), length, width, circumference, weight, volume, bulk density, dry matter, TSS (Erma hand refractometer), $\mathrm{pH} \quad$ (H196107 Hanna instruments pHep), and titratable acidity (Ranganna, 1986) was determined.

Ten tubers from each type were selected randomly. Length was recorded at longest part, width at the widest part and circumference at the broadest part of the tuber with the help of thread and scale. Length was measured in centimeter (cm). Mean was calculated and per tuber values were reported.

Weight was recorded by using single pan electronic balance and expressed in gram (g). Volume was measured by using water displacement method and expressed in millimeter (ml).

Bulk density was calculated by dividing weight of the tuber by its volume. Dry matter was noted after drying.

\section{Cooking quality and acceptability of minor tubers}

The cleaned tubers were peeled and subjected to closed lid boiling. The cooking time and gain in weight was recorded. Boiled tubers were evaluated for acceptability employing semi trained panel of judges from the Department of Food Science and Nutrition, R.H.Sc., UAS, Dharwad on a 9-point Hedonic scale.

\section{Results and Discussion}

The colour of skin and flesh of the selected minor tubers are given in the Table 1. The skin colour and flesh colour varied between the samples. The skin colour was varying from brown to grayish black and flesh colour from white to cream colour with variation in shades. Greater yam- fingers type possessed purple coloured flesh. 
Table 2 reveals the physical parameters of the selected tubers. Significant difference was seen between the tubers for physical parameters. The length of Greater yamslender type $(89.70 \mathrm{~cm})$ was significantly higher, where as it was low in Chinese potato $(2.75 \mathrm{~cm})$. But no significant difference were seen between the length of Chinese potato $(2.75 \mathrm{~cm})$, Alocasia $(9.29 \mathrm{~cm})$, Greater yamarial bulbs $(5.19 \mathrm{~cm})$, Colocasia dwarf type $(8.83 \mathrm{~cm})$, Lesser yam $(10.32 \mathrm{~cm})$, Tannia bulbs $(3.96 \mathrm{~cm})$ and Greater yam- hairy type $(7.92 \mathrm{~cm})$. The width of Elephant foot yam was significantly higher $(23.85 \mathrm{~cm})$. The width of lesser yam was significantly lower $(3.94 \mathrm{~cm})$. However, the width of all tubers except Elephant foot yam $(23.85 \mathrm{~cm})$ and Greater yam-wild edible type $(11.83 \mathrm{~cm})$ was on par with each other. Circumference of Chinese potato were significantly lower (8.77 $\mathrm{cm})$, but it was significantly higher in
Elephant foot yam $(68.45 \mathrm{~cm})$. Elephant foot yam was heavier $(2900.00 \mathrm{~g})$ with higher volume of $2950 \mathrm{ml}$. Wild type of edible Greater yam and banda type of Colocasia had the weight of more than $1700 \mathrm{~g} /$ tuber. Nevertheless, the bulk density of the tubers did not differ significantly though it ranged from 0.70 to $1.12 \mathrm{~g} / \mathrm{ml}$.

Similarly, Medhi and Parasarathy (1999) observed wide variations in corm length and corm diameter of 19 varieties of taro corms.

Perusal of Table 3 indicates that significant difference existed in TSS, $\mathrm{pH}$ and titratable acidity of the minor tubers. The TSS of Chinese potato (12.47 $\left.{ }^{\circ} \mathrm{B}\right)$, Colocasia dwarf type $\left(12.33{ }^{\circ} \mathrm{B}\right)$, bunch type of Greater yam $\left(11.87^{\circ} \mathrm{B}\right)$, hairy type of Greater yam (11.57 ${ }^{\circ}$ B) and Alocasia $\left(11.53^{\circ} \mathrm{B}\right)$ was higher and on par with each other statistically.

Table.1 Colour of selected minor tubers

\begin{tabular}{|l|l|l|l|}
\hline Sl. No. & \multicolumn{1}{|c|}{ Tuber } & \multicolumn{1}{|c|}{ Skin color } & \multicolumn{1}{c|}{ Flesh color } \\
\hline 1. & Alocasia & Light brown & Milky white \\
\hline 2. & G.Y. (arial bulbs) & Dark ash & Light yellow \\
\hline 3. & Chinese potato & $\begin{array}{l}\text { Grayish (fenugreek seed color } \\
\text { mix) }\end{array}$ & White (light cream mix) \\
\hline 4. & Colocasia (dwarf type) & Light brown & Pinkish white \\
\hline 5. & Elephant foot yam & Light blackish & Orange \\
\hline 6. & G.Y. (lion foot type) & Grayish yellow (with black mix) & Creamish white \\
\hline 7. & G.Y. (wild edible type) & Grayish black & Creamish white \\
\hline 8. & G.Y. (slender type) & Pinkish gray & $\begin{array}{l}\text { Cream color (with purple } \\
\text { pink border) }\end{array}$ \\
\hline 9. & G.Y. (fingers type) & Pinkish gray (black mix) & $\begin{array}{l}\text { Cream color (with purple } \\
\text { pink border) }\end{array}$ \\
\hline 10. & G.Y. (bunch type) & Purplish black & Purple \\
\hline 11. & Lesser yam & $\begin{array}{l}\text { Grayish (fenugreek seed color } \\
\text { mix) }\end{array}$ & Milky white \\
\hline 12. & Colocasia (banda type) & Pinkish brown & $\begin{array}{l}\text { White (light pink shaded) } \\
\text { with purple color border }\end{array}$ \\
\hline 13. & Tannia bulbs & Light brown & Milky white \\
\hline 14. & G.Y. (hairy type) & Dark grey (black ash) & Yellow \\
\hline
\end{tabular}

Note: G.Y. - Greater yam 
Table.2 Physical parameters of the minor tubers

\begin{tabular}{|c|c|c|c|c|c|c|c|}
\hline $\begin{array}{l}\text { Sl. } \\
\text { No. }\end{array}$ & Tuber & $\begin{array}{l}\text { Length } \\
\text { (cm) }\end{array}$ & $\begin{array}{l}\text { Width } \\
\text { (cm) }\end{array}$ & $\begin{array}{l}\text { Circumferenc } \\
\text { e (cm) }\end{array}$ & $\begin{array}{l}\text { Weight } \\
\text { (g) }\end{array}$ & $\begin{array}{l}\text { Volume } \\
(\mathbf{m l})\end{array}$ & $\begin{array}{c}\text { Bulk density } \\
(\mathrm{g} / \mathrm{ml})\end{array}$ \\
\hline 1. & Alocasia & $9.29 \pm 4.07$ & $8.13 \pm 2.72$ & $22.27 \pm 10.27$ & $178.22 \pm 131.78$ & $219.33 \pm 119.46$ & $0.70 \pm 0.26$ \\
\hline 2. & G.Y. (arial bulbs) & $5.19 \pm 0.70$ & $5.33 \pm 0.77$ & $14.71 \pm 2.45$ & $50.50 \pm 22.35$ & $49.80 \pm 16.13$ & $0.99 \pm 0.20$ \\
\hline 3. & Chinese potato & $2.75 \pm 0.54$ & $8.53 \pm 12.97$ & $8.77 \pm 0.61$ & $17.33 \pm 2.66$ & $15.00 \pm 3.22$ & $1.17 \pm 0.14$ \\
\hline 4. & $\begin{array}{l}\text { Colocasia (dwarf } \\
\text { type) }\end{array}$ & $8.83 \pm 2.11$ & $9.97 \pm 1.50$ & $29.59 \pm 6.04$ & $350.00 \pm 275.10$ & $335.43 \pm 188.73$ & $0.98 \pm 0.25$ \\
\hline 5. & Elephant foot yam & $15.10 \pm 3.68$ & $23.85 \pm 2.19$ & $68.45 \pm 4.17$ & $\begin{array}{c}2900.00 \pm \\
1272.79\end{array}$ & $\begin{array}{c}2950.00 \pm \\
1060.66\end{array}$ & $0.97 \pm 0.08$ \\
\hline 6. & G.Y. (lion foot type) & $33.96 \pm 7.87$ & $8.35 \pm 2.43$ & $22.86 \pm 5.33$ & $1014.92 \pm 634.28$ & $922.75 \pm 604.41$ & $1.12 \pm 0.09$ \\
\hline 7. & G.Y.(wild edible type) & $\begin{array}{c}39.90 \pm \\
12.99\end{array}$ & $11.83 \pm 2.14$ & $36.33 \pm 7.17$ & $\begin{array}{c}1788.33 \pm \\
1183.11\end{array}$ & $\begin{array}{c}1656.67 \pm \\
1094.27\end{array}$ & $1.08 \pm 0.05$ \\
\hline 8. & G.Y. (slender type) & $89.70 \pm 1.41$ & $6.20 \pm 0.71$ & $19.25 \pm 1.34$ & $1835.00 \pm 35.36$ & $1842.50 \pm 17.68$ & $0.99 \pm 0.01$ \\
\hline 9. & G.Y. (fingers type) & $\begin{array}{c}20.28 \pm \\
11.72 \\
\end{array}$ & $8.56 \pm 1.44$ & $23.50 \pm 2.99$ & $621.00 \pm 468.05$ & $597.20 \pm 475.20$ & $1.07 \pm 0.05$ \\
\hline 10. & G.Y. (bunch type) & $36.02 \pm 8.82$ & $9.15 \pm 2.15$ & $24.66 \pm 4.90$ & $1060.18 \pm 333.75$ & $923.91 \pm 277.50$ & $1.15 \pm 0.09$ \\
\hline 11. & Lesser yam & $10.32 \pm 3.37$ & $3.94 \pm 0.53$ & $11.87 \pm 1.26$ & $86.70 \pm 46.11$ & $85.10 \pm 43.62$ & $1.02 \pm 0.05$ \\
\hline 12. & $\begin{array}{l}\text { Colocasia (banda } \\
\text { type) }\end{array}$ & $33.48 \pm 8.49$ & $8.12 \pm 1.89$ & $23.66 \pm 5.02$ & $1729.20 \pm 534.54$ & $1607.40 \pm 471.87$ & $1.09 \pm 0.15$ \\
\hline 13. & Tannia bulbs & $3.96 \pm 0.67$ & $4.68 \pm 0.56$ & $12.63 \pm 1.92$ & $107.00 \pm 61.88$ & $123.80 \pm 56.78$ & $0.85 \pm 0.16$ \\
\hline 14. & G.Y. (hairy type) & $7.92 \pm 1.66$ & $7.64 \pm 1.56$ & $19.35 \pm 3.89$ & $149.60 \pm 68.26$ & $148.30 \pm 77.02$ & $1.22 \pm 0.71$ \\
\hline & Mean \pm SD & $\begin{array}{c}18.02 \pm \\
17.36 \\
\end{array}$ & $7.75 \pm 4.49$ & $20.70 \pm 10.42$ & $573.75 \pm 740.82$ & $542.12 \pm 696.42$ & $1.03 \pm 0.29$ \\
\hline & Range & $2.75-89.70$ & $3.94-23.85$ & $8.77-68.45$ & $17.33-2900.00$ & $15.00-2950.00$ & $0.70-1.12$ \\
\hline & F-value & 63.10 & 5.82 & 28.32 & 22.84 & 24.71 & 2.19 \\
\hline & SEm \pm & 2.05 & 1.25 & 1.73 & 134.17 & 122.31 & 0.10 \\
\hline & C.D. @ $1 \%$ & $7.62 * *$ & $4.64 * *$ & $6.45 * *$ & $499.56^{* *}$ & $455.43 * *$ & $\mathrm{NS}$ \\
\hline
\end{tabular}

Note: G.Y. - Greater yam

**Significant @ 0.01 level, NS-Non-significant 
Table.3 Physico chemical properties of minor tubers

\begin{tabular}{|l|l|c|c|c|}
\hline Sl. No. & \multicolumn{1}{|c|}{ Tuber } & TSS $\left(^{\circ}\right.$ Brix) & pH & Titratable acidity (\%) \\
\hline 1. & Alocasia & $11.53 \pm 0.97$ & 6.50 & $0.05 \pm 0.06$ \\
\hline 2. & G.Y. (arial bulbs) & $7.90 \pm 0.17$ & 6.40 & $0.05 \pm 0.00$ \\
\hline 3. & Chinese potato & $12.47 \pm 0.59$ & 6.70 & $0.07 \pm 0.02$ \\
\hline 4. & Colocasia (dwarf type) & $12.33 \pm 2.21$ & 6.60 & $0.08 \pm 0.02$ \\
\hline 5. & Elephant foot yam & $5.80 \pm 0.10$ & 6.70 & $0.05 \pm 0.00$ \\
\hline 6. & G.Y. (lion foot type) & $9.20 \pm 0.20$ & 6.60 & $0.07 \pm 0.02$ \\
\hline 7. & G.Y.(wild edible type) & $5.40 \pm 0.00$ & 6.40 & $0.07 \pm 0.01$ \\
\hline 8. & G.Y. (slender type) & $7.60 \pm 0.17$ & 6.90 & $0.04 \pm 0.00$ \\
\hline 9. & G.Y. (fingers type) & $5.27 \pm 0.06$ & 6.30 & $0.07 \pm 0.01$ \\
\hline 10. & G.Y. (bunch type) & $11.87 \pm 0.46$ & 6.20 & $0.05 \pm 0.01$ \\
\hline 11. & Lesser yam & $10.53 \pm 0.38$ & 7.30 & $0.06 \pm 0.01$ \\
\hline 12. & Colocasia (banda type) & $5.83 \pm 1.29$ & 6.60 & $0.05 \pm 0.01$ \\
\hline 13. & Tannia bulbs & $8.60 \pm 0.00$ & 6.40 & $0.07 \pm 0.02$ \\
\hline 14. & G.Y. (hairy type) & $11.57 \pm 1.03$ & 6.20 & $0.07 \pm 0.00$ \\
\hline & Mean \pm SD & $8.99 \pm 2.75$ & 6.56 & $0.06 \pm 0.02$ \\
\hline & F-value & 33.68 & - & 3.74 \\
\hline \multicolumn{2}{r|}{ S. Em. \pm} & 0.47 & - & 0.01 \\
\hline \multicolumn{2}{r|}{ C. D. @ 1 \% } & $1.84 * *$ & NS & $0.02 * *$ \\
\hline
\end{tabular}

Note: G.Y. - Greater yam

**Significant @ 0.01 level, NS-Non-significant

Elephant Foot yam, wild edible type of Greater yam, finger types of Greater yam and banda type of Colocasia possessed significantly lower TSS of $5.80,5.40,5.27$ and $5.83^{\circ} \mathrm{B}$. pH of minor tubers was slightly acidic ranging from 6.20-7.30, except for Lesser yam (7.30). But no significant difference was found between the tubers for $\mathrm{pH}$. Titratable acidity was found to be significantly higher $(0.08 \%)$ in Colocasiadwarf type and was on par with Chinese potato, Greater yam- lion foot type, Greater yam- wild edible type, Greater yam- fingers type, Tannia bulbs and Greater yam- hairy type $(0.07 \%)$. Titratable acidity was found lower in Greater yam- slender type $(0.04 \%)$. Dry matter content depicted in Figure 1, was significantly higher in Greater yam-bunch type (37.90\%), followed by Greater yam- slender type (35.40\%), while, lower dry matter content was seen in Colocasiabanda type (13.34 \%). This difference in the dry matter content can be attributed to the difference in moisture content of the tubers, water availability of the plant during growth, deposition of starch during maturity and the condition at which the tubers were harvested and stored. Baah et al., (2009) reported similar results for the biochemical composition of $D$. alata (Dioscorea spp.) tubers.

These differences in physical and physico chemical parameters were naturally expected as the genetic makeup of the tubers was different and possess unique physical characters. Changes in soil type, varietal differences, cultivation practices, time of planting, amount of water available and maturity of the tuber at harvest and other environmental factors might have contributed to these variations. The results of cooking quality revealed that the cooking time ranged from 11-16 min, but it was $20 \mathrm{~min}$ for elephant foot yam (Fig. 2). Percent weight gain also varied for different tubers as shown in Figure 3. It ranged from 5.17- 43.97 percent. Out of fourteen types of tubers studied, lesser yam has scored high acceptability index (93.21). Four tubers had acceptability index of 
81.85-84.69, seven tubers had acceptability index of 70.99-79.63 (Fig. 4). Alocasia and colocasia had very low acceptability index of 69.38 and 50.74 respectively. From this study, it can be concluded that among all, lesser yam was highly acceptable and colocasia was least acceptable. Cooking time did not differ, but the percent weight gain differed significantly. Increased cooking time for elephant foot yam may be due to genetic makeup and the presence of fibre. Higher weight gain on cooking in Tannia was probably due to high water absorption or water holding capacity. The taste of lesser yam was similar to potato, which is widely accepted by people. Hence, it may have scored higher acceptability index.

The reason for lower acceptances of tubers like colocasia and alocasia may be due to the presence of oxalates which increases acridity. It may also be due the fact that panel members are not used to the taste of these tubers. Few processing techniques involving preparation of savory products with addition of acid may minimize the acridity and also improve its acceptability.

The difference in the values of physical and physico chemical parameters of the minor tubers indicates a wide variation among the tubers. Due to good cooking quality and acceptability index processing helps to enhance the acceptance of the tubers. Converting these tubers into other value added products may add to the best utilization of tubers as functional and health foods. Thus improves the income of farmers by lowering the post-harvest losses.

\section{References}

Anonymous, 2013, Annu. Rep. (2012-13), Central Tuber Crops Research Institute,
Thiruvananthapuram, Kerala, pp. 12, 68.

Baah, F. D., Dixon, B., Asiedu, R., Oduro, I. and Ellis, W. O., 2009, Nutritional and biochemical composition of $D$. alata (Dioscorea spp.) tubers. J. Food, Agric. Environ., 7 (2): 373-378.

Hoover, R., 2001, Composition, molecular structure, and physicochemical properties of tuber and root starches: A review. Carbohydrate Polymers, 45(3): 253-267.

Judprasong, K., Tanjor, S., Puwastien, P. and Sungpuag, P., 2011, Investigation of Thai plants for potential sources of inulin-type fructans. Journal of Food Composition and Analysis, 24(4): 642-649.

Lai, Y. C., Huang, C. L., Chan, C. F., Lien, C. Y., and Liao, W. C., 2013, Studies of sugar composition and starch morphology of baked sweet potatoes (Ipomoea batatas L. Lam). Journal of Food Science and Technology, 50(6): 1193-1199.

Medhi, R. P. and Parthasarathy, V. A., 1999. Crop improvement in taro in North Eastern region. In: Tropical tuber crops in food security and nutrition. Ed. Balagopalan, C., Nayar, T. V. R., Sundaresan, S., Premkumar, T. and Lakshmi, K. R., Oxford and IBH publishing Co. Pvt. Ltd., New Delhi, pp. 183-185.

Moongngarm, A., Trachoo, N. and Sirigungwan, N., 2011. Low molecular weight carbohydrates, prebiotic content, and prebiotic activity of selected food plants in Thailand. Advance Journal of Food Science and Technology, 3(4): 269-274.

Viswanathan, M. B., 2004. Ethnobotanically important plants. In: Tamil Nadu Biodiversity strategy and action plan (ed.) R. Annamalai, Tamil Nadu Biodiversity strategy and action plan Published by Tamil Nadu Forest Department Chennai, pp. 177231.

\section{How to cite this article:}

Divya Parmeshwar Mesta, Pushpa Bharati and Sunanda K. Itagi. 2017. Physico-Chemical Analysis, Cooking Quality and Acceptability of Minor Tubers. Int.J.Curr.Microbiol.App.Sci. 6(11): 3294-3299. doi: https://doi.org/10.20546/ijcmas.2017.611.386 